\author{
dr Agnieszka LOREK \\ Wydział Ekonomii, Uniwersytet Ekonomiczny w Katowicach \\ e-mail: agnieszka.lorek@ue.katowice.pl
}

DOI: $10.15290 /$ ose.2016.06.84.09

\title{
OCENA RELACJI SPOLECZNYCH I ŚRODOWISKOWYCH MIĘDZY ADMINISTRACJĄ SAMORZĄDOWĄ A SPOLECZNOŚCIĄ LOKALNĄ W WYBRANYCH WOJEWÓDZTWACH
}

\begin{abstract}
Streszczenie
Celem artykułu jest prezentacja oraz ocena relacji społecznych między władzą samorządową a mieszkańcami (ze szczególnym uwzględnieniem problemów ochrony środowiska) w gminach województw: śląskiego, wielkopolskiego i podlaskiego. Podstawowymi metodami badawczymi zastosowanymi w artykule były: metoda porównawcza, badania studiów przypadku i metody ankietowe. Badania ankietowe przeprowadzono wśród samorządów terytorialnych i mieszkańców. Głównym źródłem informacji wykorzystanym w artykule były badania ankietowe, które w 2015 roku zrealizowano wśród gmin województw: śląskiego, podlaskiego i wielkopolskiego. Ankietę skierowano do wszystkich gmin powyższych województw, a ogółem uzyskano zwrot 261 ankiet $(50,2 \%)$. W artykule przedstawiono takie kwestie, jak:

- $\quad$ przyczyny protestów społecznych i konfliktów ekologicznych w badanych gminach;

- prowadzenie działań edukacyjnych i promowanie zachowań proekologicznych, a także badań satysfakcji odbiorców usług komunalnych przez analizowane samorządy terytorialne.

Uzyskane wyniki pokazały, że najczęściej konflikty ekologiczne w gminach dotyczyły inwestycji w odnawialne źródła energii. Wykazały zarazem braki związane z polityką informacyjno-edukacyjna (ograniczenie się w działaniach do ustawowego minimum), jak również nieprowadzeniem monitoringu usług publicznych świadczonych przez gminy, co przełożyło się na spadek zaufania mieszkańców.
\end{abstract}

Słowa kluczowe: konflikt ekologiczny, komunikacja z mieszkańcami, samorząd lokalny

\section{ASSESSMENT OF SOCIAL AND ENVIRONMENTAL RELATIONSHIPS BETWEEN LOCAL GOVERNMENTS AND COMMUNITIES IN SELECTED PROVINCES}

\section{Summary}

The purpose of this paper is to present and assess the social relationships between local authorities and residents (particularly in terms of environmental issues) in the municipalities of Śląskie, Wielkopolskie, and Podlaskie voivodeships. The basic research methods include: comparative research, case studies, and surveys conducted among municipalities and residents. The main source of information was a survey conducted in the municipalities of the three above-mentioned voivodeships in 2015. The survey was addressed to all the municipalities of these provinces, and achieved a total return of 261 questionnaires $(50.2 \%)$. The paper presents such issues as: 
- $\quad$ causes of social protests and ecological conflicts in surveyed municipalities,

- educational activities and promotion of ecological behaviour, as well as monitoring satisfaction of buyers of public services by analyzed local governments.

The results indicate that the most common ecological conflicts in the communities in question are related to investments in renewable energy sources. They also point to shortcomings in information and education policies (limitation of activities to the statutory minimum) and failure to monitor public services provided by the municipalities, which has undermined public confidence.

Key words: ecological conflict, public services, municipalities

JEL: Q01

\section{Wstęp}

Odrodzenie samorządności lokalnej po 1989 roku włączyło społeczność lokalną w proces zarządzania rozwojem. Reforma ta dała możliwości oraz prawo samorządom terytorialnym do decydowania o kształtach i kierunkach procesów rozwojowych, w imieniu i uwzględniając interesy mieszkańców, jak również ich prawo do informacji o planowanych zamierzeniach. Należy pamiętać, że programowanie rozwoju (także na poziomie lokalnym) jest zadaniem bardzo złożonym i obarczonym wieloma uwarunkowaniami, w tym bardzo istotnymi ograniczeniami związanymi z jakością środowiska. Stan środowiska naturalnego w bezpośredni sposób rzutuje na jakość życia mieszkańców, a postawy mieszkańców mają wpływ na stan środowiska. Stawia to przed samorządem nowe zadania dotyczące kształtowania pożądanych postaw obywatelskich. Jednocześnie obszar obejmujący środowisko często jest płaszczyzną wybuchu potencjalnych konfliktów. Obywatele o postawie proekologicznej moga protestować przeciwko niszczeniu środowiska, a osoby o niskim poziomie wiedzy ekologicznej nie będą chciały akceptować rozwiązań proekologicznych.

Celem artykułu jest prezentacja oraz ocena relacji społecznych między władzą samorządową a mieszkańcami (ze szczególnym uwzględnieniem problemów ochrony środowiska) skierowana do samorządów terytorialnych województw: śląskiego, wielkopolskiego i podlaskiego. W artykule wykorzystano: podejście indukcyjne i metodę porównawcza, badania studiów przypadku i metody ankietowe. Badania oparto zarówno na podejściu diagnostycznym, jak i prognostycznym, głównymi, którymi posłużono się w artykule, były badania przeprowadzone w ramach badań statutowych Katedry Polityki Społecznej i Gospodarczej pt.: Polityka zrónnoważonego rozwoju w wymiarze krajomym, regionalnym $i$ lokalnym i realizowane w latach 2013-2015. Na potrzeby badań statutowych w roku 2015 zrealizowano badania ankietowe wśród samorządów terytorialnych w gminach województw: podlaskiego, wielkopolskiego oraz śląskiego. Wybrano do nich województwa zróżnicowane, biorąc pod uwagę następujące aspekty: położenie geograficzne, różnice społeczne i kulturowe, uwarunkowania środowiskowo-przyrodnicze i zasobowe, wyposażenie w infrastrukturę techniczną i społeczna, profil gospodarczy i jakość życia. Uznano iż, taki rozkład przestrzenny badanych województw jest reprezentatywny dla Polski. Ankietę skierowano do wszystkich gmin powyższych województw, a ogółem uzyskano zwrot 261 ankiet (50,2\%). Otrzymane wyniki ankiety 
uzupełniono analizą wcześniej zrealizowanych badań ankietowych wśród gmin województwa śląskiego w latach 2012-141 i mieszkańców tego województwa w latach 1999$2000^{2}$ i $2012-14^{3}$, innych dostępnych danych oraz raportów tematycznych. Ankiety wśród samorząaów terytorialnych w obu edycjach przeprowadzono metodą CAWI, a z powodu niewystarczającego zwrotu uzupełniono przez wysłanie ankiet droga pocztowa. Badania wśród mieszkańców objęły województwo śląskie i były przeprowadzone na reprezentatywnej grupie metodą wywiadu za pośrednictwem kwestionariusza ankiety.

\section{Konflikty ekologiczne na poziomie lokalnym}

Konflikty ekologiczne są szczególnym rodzajem konfliktów społecznych. Obejmuja one obszar zwiazany z użytkowaniem środowiska, wykorzystywaniem jego zasobów, w tym ograniczonej przestrzeni, a także szkodliwego oddziaływania na jego jakość. Potencjalnym obszarem konfliktowym są również pewne rodzaje zamierzeń inwestycyjnych, czy to realizowane przez władze publiczne, czy przez podmioty prywatne. Tego typu lokalne konflikty wyrażają się protestami okolicznych mieszkańców przeciwko lokalizacji pewnych obiektów w ich bezpośrednim otoczeniu i wiążą się z rozpoznaniem zagrożenia swoich interesów przez jednostki i grupy. Konflikty takie trwają niekiedy nawet kilkanaście lat i łączą się z wielkimi wydatkami, zarówno w sensie bezpośrednim (koszty sporządzania dodatkowych ekspertyz, koszty procesów sądowych itd.), jak i w sensie „kosztów utraconych możliwości” (związanych z zamrożeniem budowy). Na podstawie wyników badań ankietowych przeprowadzonych wśród gmin: województw śląskiego, wielkopolskiego i podlaskiego można stwierdzić, że konflikty na płaszczyźnie środowiskowej najczęściej dotyczyły inwestycji w zakresie: odnawialnych źródeł energii, zanieczyszczeń powodowanych przez zakłady przemysłowe oraz lokalizacji obiektów związanych z gospodarką komunalną (tabela 1.).

1 To badania statutowe Katedry Zarządzania Ochroną Środowiska Uniwersytetu Ekonomicznego w Katowicach pt.: Rozpój rynku dóbri ustug ekologicznych w warunkach gospodarki polskiej, których współautorką była m.in. A. Lorek.

${ }^{2}$ Jest to grant KBN, Nr 1H02C03615 pt.: Rozwój rynku dóbr i ustug ekologicznych w wojewódz̨twie katowickim w warunkach restrukturyzacji gospodarki", a ich współautorką była m. in. A. Lorek.

3 To badania statutowe Katedry Zarządzania Ochroną Środowiska Uniwersytetu Ekonomicznego w Katowicach pt.: Rožnój rynku dóbr i ustug ekologicznych w warunkach gospodarki polskiej, ich współautorką także była m.in. A. Lorek. 
TABELA 1.

\section{Samorządy terytorialne, które odnotowały protesty społeczne (w \% ważnych odpowiedzi)}

\begin{tabular}{|c|c|c|c|c|}
\hline $\begin{array}{l}\text { Czego dotyczył } \\
\text { protest }\end{array}$ & Ogółem & $\begin{array}{l}\text { Wojewódz- } \\
\text { two podlas- } \\
\text { kie }\end{array}$ & $\begin{array}{l}\text { Wojewódz- } \\
\text { two śląskie }\end{array}$ & $\begin{array}{l}\text { Wojewódz- } \\
\text { two wielko- } \\
\text { polskie } \\
\end{array}$ \\
\hline $\begin{array}{l}\text { Lokalizacja obiektów } \\
\text { związanych z gospo- } \\
\text { darka komunalną }\end{array}$ & 21,2 & 16,3 & 25 & 19,4 \\
\hline $\begin{array}{l}\text { Budowa nowych zak- } \\
\text { ładów przemysłowych }\end{array}$ & 18,9 & 13,9 & 22,2 & 17,6 \\
\hline $\begin{array}{l}\text { Inwestycje zwiazzane } \\
\text { z OZE }\end{array}$ & 36,3 & 34,9 & 16,7 & 56,5 \\
\hline Budowa dróg & 13,5 & 11,6 & 17,6 & 10,2 \\
\hline $\begin{array}{l}\text { Zła jakość środowis- } \\
\text { ka naturalnego }\end{array}$ & 7,7 & 4,7 & 12 & 4,6 \\
\hline $\begin{array}{l}\text { Zanieczyszczenia po- } \\
\text { wodowane przez zak- } \\
\text { lady przemysłowe }\end{array}$ & 22,1 & 7 & 30,6 & 19,6 \\
\hline $\begin{array}{l}\text { Wycinka drzew przyd- } \\
\text { rożnych i w parkach }\end{array}$ & 17 & 11,6 & 18,5 & 11,6 \\
\hline $\begin{array}{l}\text { Likwidacja obszarów } \\
\text { zieleni pod inwestycje }\end{array}$ & 7,8 & 7,1 & 9,3 & 6,5 \\
\hline $\begin{array}{l}\text { Zbyt wysokie opłaty } \\
\text { za usługi komunalne }\end{array}$ & 15,8 & 17,6 & 17,6 & 6,8 \\
\hline
\end{tabular}

Źródło: opracowanie własne na podstawie wyników badań ankietowych.

Inwestycje związane z odnawialnymi źródłami energii (OZE) są zagadnieniem, z którym najczęściej wiążą się protesty społeczne (ponad 36\% gmin przyznało, że na ich obszarze wystapiły takie protesty). Najczęściej protesty tego typu zanotowano w województwie wielkopolskim (w ponad 56\% gmin) i podlaskim (około $35 \%$ ankietowanych), najrzadziej w województwie śląskim (16,7\% gmin). Województwa wielkopolskie i podlaskie są regionami o dobrze rozwiniętym rolnictwie, a co jest z tym związane, istotnym potencjale rozwoju biogazowni rolniczych, które są obiektami budzącymi duże kontrowersje wśród mieszkańców. W Polsce, niemal w każdym przypadku, gdy ma powstać biogazownia rolnicza, mieszkańcy protestuja przeciwko jej budowie i próbuja taką budowę zablokować. Ciekawe wnioski płyną z opracowania firmy Euro SCG Sensors (obecnie Havas Worldwide) pt.: Dlaczego inwestycje w budowe biogazowni rolnicsych napotykaja na opór spoteczny?. Jego autor, Mariusz Wawer, wyliczył, że aż 160 takich inwestycji w Polsce zderza się z silnym i jawnym oporem społecznym, a kolejne kilkadziesiąt może być zagrożone ze względu na brak komunikacji społecznej inwestorów i władz. Przyczyną takiego stanu rzeczy jest to, że inwestorzy i samorządy niejednokrotnie zaczynają rozmawiać z lokalną społecznością o budowie biogazowni (tłumaczyć, czym one są, przekonywać, że nie stanowia zagrożenia dla otoczenia) dopiero wtedy, gdy wybuchnie protest. Częstym sposobem postępowania w czasie tych konsultacji jest idealizowanie 
takich inwestycji i pomijanie związanych z nimi ryzyk i wad instalacji biogazowych, co czyni taki przekaz niewiarygodnym. Euro SCG Sensors oceniło, że mieszkańcy protestują m.in. dlatego, że boją się zmiany, obniżenia bezpieczeństwa i komfortu życia, a również brakuje im wiarygodnych źródeł informacji na temat biogazowni, które rozwiałyby wattpliwości i obawy. Zwykle scenariusz protestu przeciwko budowie biogazowni wygląda tak, że na początku tylko 5-15\% lokalnej społeczności jest przeciwna takiej inwestycji, a $60-85 \%$ ma neutralne stanowisko. Jeśli jednak inwestor i lokalne władze w porę oraz odpowiednio nie zareaguja na ten sprzeciw, organizując choćby spotkania z mieszkańcami, to wówczas wiele osób o neutralnym wcześniej nastawieniu przechodzi na stronę przeciwników inwestycji. Często więc efekt jest taki, że grupa protestujących zwiększa się z 5-10\% danej społeczności do ponad 50\%. Dlatego właśnie inwestorzy i lokalne władze powinny zaczynać rozmowy z mieszkańcami jak najwcześniej, jeszcze zanim zaczną się przygotowywania do inwestycji i zanim ruszą formalności z nią związane [Krzemiński, 2016]. Równie duże problemy dotyczą inwestycji w energetykę wiatrowa. W raporcie pt.: Konflikty społeczne w energetyce wiatrowej, realizowanym przez Ambiens Sp. z o. o., prawie 90\% respondentów, którymi były podmioty realizujące inwestycje w energetyce wiatrowej, spotkało się $z$ problemem konfliktów społecznych podczas realizowania inwestycji. Głównymi powodami wybuchu konfliktów były obawy społeczności lokalnej obejmujące:

- pogorszenie komfortu życia (np.: hałas, efekt migotania) - 94\% odpowiedzi;

- $\quad$ spadek wartości nieruchomości - 76\% odpowiedzi;

- zagrożenia dla zdrowia - $72 \%$ odpowiedzi;

- dewastacja krajobrazu - 56\% odpowiedzi;

- negatywny wpływ na przyrodę - $44 \%$ odpowiedzi;

- $\quad$ inne czynniki, np. koszt prądu z OZE, za mała odległość od domów, kwestie finansowe $-14 \%$ odpowiedzi.

Druga pozycja pod względem ilości protestów dotyczyła zanieczyszczeń powodowanych przez zakłady przemysłowe. Zagadnienie to było najczęściej odnotowywanym powodem protestów w województwie śląskim (30,6\% ankietowanych gmin zauważa takie protesty). Problem ten był również istotny w województwie wielkopolskim - około $20 \%$ gmin zauważa takie protesty. Obecnie najważniejszy konflikt tego typu w województwie śląskim wiąże się z działalnością przemysłową w Dąbrowie Górniczej. W mieście tym odnotowano najwyższe emisje zanieczyszczeń pyłowych - 4,0 tys. t (39,4\% ogólnej emisji w województwie) oraz gazowych (bez dwutlenku węgla) - 154,3 tys. t $(21,3 \%)$ w województwie [Stan środowiska..., 2015, s. 14]. Mieszkańcy dzielnicy Strzemieszyce protestują przeciwko skażeniu środowiska w dzielnicy, a szczególnie przeciwko nadmiernej koncentracji zakładów przemysłowych na tym obszarze. Protesty dotyczyły: budowy i rozbudowy zakładów przeróbki odpadów (np. przeciwko planom budowy kompostowni przez firmę Remondis), spalania odpadów niebezpiecznych (zablokowany transport niebezpiecznych odpadów z Salwadoru przeznaczony do utylizacji w Sarpi Sp. z o. o.), działalności Arcelor Mittal Poland SA (emisja pyłu stalowego w sposób niezorganizowany, nielegalny wywóz odpadów, skażenia gruntów). Zastrzeżenia protestujących budzi także bierna postawa władz miejskich oraz brak konsultacji społecznych w sprawach istotnych dla mieszkańców. 
Wiele gmin zauważa także problem powstawania konfliktów w trakcie lokalizacji nowych zakładów przemysłowych, które potencjalnie mogą mieć negatywny wpływ na jakość życia społeczności lokalnych i na środowisko. Konflikty takie najczęściej dotyczyły województwa: śląskiego - ponad 22\% gmin (region śląski jest silnie zurbanizowany i uprzemysłowiony, dlatego też występuje konkurencja o ograniczoną przestrzeń i protesty przeciwko nadmiernej koncentracji zakładów przemysłowych wywierających negatywny wpływ na środowisko), następnie wielkopolskiego - ponad $17 \%$ ankietowanych. W Polsce najpoważniejsze konflikty tego typu w chwili obecnej sa związane z budową kopalni odkrywkowych na obszarach Dolnego Śląska oraz Wielkopolski. Zamiary te budzą istotny opór społeczny oraz mobilizację społeczności lokalnej przeciwko takiej inwestycji (liczne demonstracje, marsze, pikiety, petycje itp.). Przykładem takiego konfliktu na obszarze objętym badaniami ankietowymi jest przypadek protestów przeciwko budowie kopalni odkrywkowej węgla brunatnego przez spółkę PAK Górnictwo ${ }^{4}$, związany z takimi gminami, jak: Krobia i Miejska Górka (Wielkopolska). Społeczność lokalna nie godzi się na inwestycję ingerującą w tak istotny sposób w środowisko, gdyż obawia się: zniszczenia rolnictwa na tym obszarze, degradacji gleb, obniżenia poziomu wód gruntowych, jak również zniszczenia wielu społeczności lokalnych i wysiedleń. W sprawie tej odbyło się 21 czerwca 2015 roku referendum w gminie Babiak [Komunikat Wójta..., 2015], gdzie 91\% mieszkańców opowiedziało się przeciw kopalni odkrywkowej. Konflikt ten jest wielowymiarowy (jednocześnie wiąże się z brakiem konsultacji z mieszkańcami władz lokalnych w gminach: Krobia i Miejska Górka), a protesty trwaja do chwili obecnej.

Kolejnym polem rozwoju potencjalnych konfliktów jest cały obszar gospodarki komunalnej, a zwłaszcza lokalizacja obiektów gospodarki komunalnej (spalarnie odpadów, kompostownie, wysypiska) oraz kwestie łączące się z funkcjonowaniem poszczególnych systemów. Problemy związane z lokalizacją najczęściej odnotowały gminy województwa śląskiego - 25\% ankietowanych gmin. Przykładem mogą być, wcześniej wspomniane, protesty w Dąbrowie Górniczej dotyczące budowy kompostowni czy problemy przy lokalizacji spalarni odpadów dla Aglomeracji Śląskiej. Obiekty takie są szczególnie niechcianymi inwestycjami i często je obejmuje syndrom NIMBY (Not In My Back Yard). Mieszkańcy obawiają się uciążliwości związanych z: funkcjonowaniem zakładu, nieprzestrzeganiem norm środowiskowych i obniżeniem wartości posiadanych przez nich nieruchomości.

Inną kwestia, która może budzić opór społeczny, jest problem akceptacji konieczności ponoszenia opłat za świadczone usługi komunalne. Niejasne kryteria ustalania opłat czy też mało klarowne kierunki wydatkowania pozyskanych środków mogą skutkować niskim stopniem zaufania do władz gminnych, a w rezultacie niechęcią do ponoszenia opłat na te cele. Protesty mieszkańców w tym zakresie odnotowało 17,6\% gmin w województwie podlaskim i śląskim i prawie $16 \%$ w województwie wielkopolskim, jednak większość ankietowanych gmin (prawie 55\%) uznała niską skłonność do ponoszenia obciążeń w ramach ochrony środowiska za istotną barierę rozwoju. Największe obawy dotyczące niechęci mieszkańców do ponoszenia wydatków w zakresie ochrony

\footnotetext{
${ }^{4}$ PAK Górnictwo to spółka powołana do zapewnienia bazy paliwowej dla elektrowni Pątnów Adamów - Konin.
} 
środowiska wyraziły gminy województwa śląskiego - 59,6\% ankietowanych gmin. Województwo śląskie jest obszarem z dużym nagromadzeniem różnorodnych problemów środowiskowych (dostrzeganych przez mieszkańców, co potwierdziły wyniki wielu badań opinii publicznej) $)^{5}$, natomiast sytuacja ekonomiczna województwa na tle Polski jest dobra (pomijając strukturalne problemy sektora górnictwa kamiennego), przykładowo:

- PKB w 2013 roku (ceny bieżące) na 1 mieszkańca w zł był następujący: województwo ślaskie 44760 (województwo podlaskie - 31 362, województwo wielkopolskie - 46 135) [Wojewódz̨two ślaskie..., 2016];

- przeciętne miesięczne wynagrodzenie brutto w sektorze przedsiębiorstw w województwie śląskim nie odbiega od średniej krajowej i w 2015 roku wynosiło 4 329,71 zł [Województwo ślaskie..., 2016; Wybrane dane..., 2016];

- $\quad$ stopa bezrobocia rejestrowanego (stan z 31 maja 2016 roku) dla województwa śląskiego stanowiła 7,6\% (wskaźnik dla Polski - 9,1\%) [Wybrane dane..., 2016];

- $\quad$ w województwie śląskim procentowy udział osób w gospodarstwach domowych o wydatkach poniżej granicy ubóstwa skrajnego w 2014 roku był najniższy w kraju i wynosił 4,7\% (Polska - 7,4\%, województwo wielkopolskie 10,1\%, województwo podlaskie - 10,9\%) [Ubóstwo w Polsce..., 2016].

Jednak wzrost gospodarczy i rosnący poziom życia mieszkańców województwa w ostatnich latach nie przekłada się na ich skłonność do ponoszenia opłat związanych z ochroną środowiska. Według badań ankietowych przeprowadzanych wśród mieszkańców regionu ${ }^{6}$, odsetek osób deklarujacych taka gotowość w ostatnich latach uległ znacznemu zmniejszeniu. Zgodnie $\mathrm{z}$ danymi uzyskanymi w badaniach ankietowych $\mathrm{w}$ roku 1999, chęć taką deklarowało 75\% uczestników badania, rok później, w 2000 roku, gotowość do ponoszenia dodatkowych opłat na rzecz środowiska deklarowało 64\%, zaś w edycji badań realizowanych w latach 2012-2014 było to około 50\% respondentów. Można zatem stwierdzić, że świadomość ekologiczna mieszkańców regionu często przybiera postać deklaratywną - wprawdzie są dostrzegane problemy i zagrożenia, ale mieszkańcy oczekują działań ze strony innych podmiotów i instytucji, a także nie chcą ponosić dodatkowych opłat na ten cel. Taka sytuacja stwarza szczególne wyzwanie dla samorządów terytorialnych, które nie tylko muszą sprostać wymaganiom mieszkańców dotyczącym zabezpieczenia stanu środowiska naturalnego, lecz również powinny podjąć aktywne działania informacyjno-edukacyjne mające na celu przekonanie mieszkańców do zasadności ponoszenia wydatków na rzecz poprawy jakości środowiska naturalnego i przystapienia do czynnych działań w tym zakresie.

\footnotetext{
${ }^{5}$ Przykładem mogą być badania ankietowe przeprowadzone w latach 2012-2014 wśród mieszkańców województwa śląskiego w ramach badań statutowych Katedry Zarządzania Ochroną Środowiska Uniwersytetu Ekonomicznego w Katowicach, w których uczestniczyła autorka niniejszego artykułu. Według tych badań, zanieczyszczenie powietrza badani uznali za najpoważniejszy problem środowiskowy.

${ }^{6}$ Były to badania ankietowe, które realizowano w latach 1999-2000 i 2012-2014 wśród mieszkańców województwa śląskiego.
} 


\section{Komunikacja z mieszkańcami}

Partycypacja społeczna polega na angażowaniu wszystkich grup społecznych w wypracowywanie rozwiązań lokalnych problemów i podejmowanie decyzji w istotnych dla nich sprawach. Jej sukces zależy od jakości lokalnego kapitału społecznego, stąd tak ważne są działania prowadzące do jego rozwoju i pełnego wykorzystania potencjału wszystkich członków lokalnej społeczności [Wyzwania zৃónnoważonego rozwoju w Polsce, 2010, s. 26]. Aktywne włączanie w proces decyzyjny społeczności lokalnych jest również przykładem wyrażania swoich potrzeb przez jednostki i grupy społeczne. Współcześnie społeczeństwa stają się coraz bardziej wymagające w stosunku do jakości decyzji, jakie podejmują władze publiczne różnych szczebli, oraz same organizują się na rzecz obrony własnych interesów w różne formy zrzeszeń, tj.: organizacji obywatelskich, stowarzyszeń zawodowych czy gospodarczych. Dla polityków i urzędników oznacza to przede wszystkim konieczność liczenia się z głosem grup i organizacji niezależnych od władz oraz zainteresowanych wpływem na kształt decyzji podejmowanych przez instytucje publiczne [Długosz, Wygnański, 2005, s. 11]. Władze publiczne powinny zatem traktować stronę społeczna jak równorzędnego partnera, a nie sprowadzać ją do roli organu doradczego [Borys, 1998]. Równocześnie należy zwrócić uwagę na to, że autokratyczna osobowość rządzących może stanowić istotną barierę związaną z uspołecznieniem procesu podejmowania decyzji, podobnie jak wcześniejsza historia stosunków z lokalną społecznością (np. istniejące konflikty) czy silna identyfikacja władz z jedna z opcji politycznych. Bariery te muszą zostać przezwyciężone dzięki budowie zaufania na podstawie efektywnej komunikacji. Powinna ona umożliwiać obywatelom i innym interesariuszom dostęp do informacji o: zamierzeniach, planach i możliwościach zaangażowania się, a nie tylko o podjętych już decyzjach [Kwiatkowski, 2003].

Jednocześnie partycypacja społeczna wymaga prowadzenia skoordynowanych działań edukacyjnych obejmujących kształtowanie postaw proekologicznych. Te są niezbędnym elementem skutecznego działania wielu usług publicznych o charakterze środowiskowym, np. system gospodarki odpadami komunalnymi nie ma szans na skuteczne funkcjonowanie bez pełnego udziału społeczeństwa dotyczącego: segregacji odpadów, zaprzestania spalania ich w piecach i porzucania w lasach itp. Wysoki poziom świadomości ekologicznej jest zarazem kluczowy dla poprawy wielu aspektów związanych z jakościa środowiska, np. jakością powietrza (wspomniane spalanie odpadów) czy ochroną bioróżnorodności. Według przeprowadzonych badań, ankietowane samorządy za istotną barierę rozwoju uznały następujące: ugruntowane nawyki i zachowania mieszkańców (ponad 75\% ankietowanych gmin) oraz niski poziom wiedzy i świadomości ekologicznej (48\%). W rozbiciu na poszczególne województwa problemy przedstawiono poniżej.

1. Gminy województwa śląskiego - prawie $82 \%$ ankietowanych samorządów za barierę rozwoju uznało złe i ugruntowane nawyki mieszkańców, jednocześnie większość gmin stwierdziła, iż mieszkańcy mają wystarczający poziom wiedzy związanej z ochroną środowiska (53,9\% ankietowanych).

2. Gminy województwa podlaskiego - gminy województwa podlaskiego najrzadziej za barierę uznawały nawyki mieszkańców, chociaż wciąż jest to wysoki 
poziom $(64,4 \%)$. Samorządy te równocześnie najgorzej oceniły poziom wiedzy ekologicznej mieszkańców - ponad 51\% samorządów stwierdziła, że nie posiadają oni wystarczającego zasobu informacji w zakresie ochrony środowiska.

3. Gminy województwa wielkopolskiego - prawie $74 \%$ ankietowanych samorządów za barierę rozwoju uznało złe nawyki mieszkańców oraz ponad połowa $(51,5 \%)$ - poziom wiedzy obywateli za wystarczający.

Większość ankietowanych gmin (60,8\%) prowadzi działania edukacyjne dotyczące promowania postaw proekologicznych, a działania te najczęściej były określane jako średnio zaawansowane (51\% ważnych odpowiedzi). Najczęściej prowadzenie takich działań deklarowały gminy województwa śląskiego (około 74\% ankietowanych), najrzadziej gminy województwa podlaskiego - około 47\% (tabela 2.), mimo iż samorządy tego województwa najgorzej oceniły poziom wiedzy mieszkańców.

TABELA 2.

Promowanie proekologicznych zachowań przez władze samorządowe w roku 2015 (w \% ważnych odpowiedzi)

\begin{tabular}{|l|c|c|}
\hline \multirow{2}{*}{ Województwo } & \multicolumn{2}{|c|}{$\begin{array}{r}\text { Promowanie proekologicznych zachowań - } \\
\text { realizowane przez gminę }\end{array}$} \\
\cline { 2 - 3 } & tak & nie \\
\hline podlaskie & 46,7 & 53,3 \\
śląskie & 73,8 & 26,2 \\
wielkopolskie & 53,7 & 46,3 \\
ogółem & 60,8 & 39,2 \\
\hline
\end{tabular}

Źródło: opracowanie własne na podstawie wyników badań ankietowych.

TABELA 3.

Poziom zaawansowania edukacji ekologicznej w gminie, w roku 2015 (w \% ważnych odpowiedzi)

\begin{tabular}{|l|c|c|c|c|c|}
\hline \multirow{2}{*}{ Województwo } & \multicolumn{6}{|c|}{ Poziom zaawansowania edukacji ekologicznej } \\
& \multicolumn{5}{c|}{ w gminie } \\
\cline { 2 - 6 } & $\begin{array}{c}\text { brak } \\
\text { działań }\end{array}$ & $\begin{array}{c}\text { pilota- } \\
\text { żowe }\end{array}$ & $\begin{array}{c}\text { począt- } \\
\text { kujące }\end{array}$ & $\begin{array}{c}\text { średnio } \\
\text { zaawanso- } \\
\text { wane }\end{array}$ & $\begin{array}{c}\text { bardzo zaa- } \\
\text { wansowane }\end{array}$ \\
\hline podlaskie & 11,9 & 11,9 & 28,6 & 40,5 & 7,1 \\
ślaskie & 2,8 & 3,7 & 16,8 & 50,5 & 26,2 \\
wielkopolskie & 6,6 & 1,9 & 20,7 & 55,7 & 15,1 \\
ogółem & 5,9 & 4,3 & 20,4 & 51 & 18,4 \\
\hline
\end{tabular}

Źródło: opracowanie własne na podstawie wyników badań ankietowych.

W większości prowadzone działania wiążą się z gospodarką odpadami komunalnymi (segregacja odpadów, organizacja nowego systemu, spalanie odpadów w piecach) i przyjmują różnorodne formy (ulotki, spotkania informacyjne, strona internetowa, edukacja 
w szkołach i akcje „sprzątania świata”). Należy zauważyć, że zgodnie ze znowelizowaną Ustawa o utryymaniu porzqdk u i crystości w gminach, gmina ma obowiązek prowadzenia działań informacyjno-edukacyjnych w zakresie prawidłowego gospodarowania odpadami komunalnymi. Inne obszary aktywności edukacyjno-informacyjnej gmin obejmują (zaczynając od najczęściej wymienianych, oprócz gospodarki odpadami komunalnymi):

- ochronę powietrza i likwidację niskiej emisji (likwidację pieców węglowych),

- utylizację azbestu,

- wypalanie traw,

- gospodarkę niskoemisyjna,

- oszczędzanie energii,

- ochronę wód,

- rozwój odnawialnych źródeł energii (budowa turbin wiatrowych, biogazowni, fotowoltaika),

- ochronę lasów,

- informacje dotyczące konieczności ochrony płazów,

- zachowanie czystości w mieście,

- ochronę przed hałasem,

- budowę infrastruktury (spalarnie odpadów komunalnych, oczyszczalnie ścieków, nowe drogi).

Ze względu na zły stan powietrza za szczególnie istotne w Polsce (dotyczy to również badanych województw) należałoby uznać działania edukacyjne związane z ochroną powietrza i likwidacją niskiej emisji. Jednak działania te wymagaja znacznej intensyfikacji. Większość ankietowanych gmin w swojej działalności w zakresie edukacji ekologicznej ogranicza się jedynie do wypełnienia obowiązkowego minimum (edukacja dzieci w szkole, kampania informacyjna w ramach wdrażania nowego systemu gospodarki odpadami komunalnymi), natomiast, wskazane powyżej, inne obszary aktywności informacyjno-edukacyjnej są wymieniane przez pojedyncze samorządy.

Niezbędnym elementem działań samorządów na poziomie lokalnym powinno być także stałe monitorowanie jakości podstawowych usług, za które jest odpowiedzialny samorząd terytorialny. Aby zyskać zaufanie mieszkańców i ich akceptację dla podjętych działań, władze gminne powinny większą uwagę zwracać na jakość usług świadczonych przez firmy zajmujące się gospodarką komunalna. Obserwowane przez mieszkańców nieprawidłowości (np.: przypadki mieszania odpadów zbieranych selektywnie ze zbieranymi nieselektywnie, niepunktualność transportu publicznego) oraz niezadowolenie z poziomu usług powoduja niechęć do rozwiązań proekologicznych lub zaprzestanie korzystania $z$ usług (np. rezygnacja $z$ transportu publicznego na rzecz samochodu). Odpowiedzi na pytanie dotyczące przeprowadzania przez gminy badań satysfakcji odbiorców usług wykazały zdecydowane braki monitoringu jakości usług komunalnych. Gminy, które w tym zakresie wskazały na aktywność, w większości realizowały go sporadycznie. W województwie podlaskim tylko jedna gmina zadeklarowała prowadzenie monitoringu jakości usług komunalnych, w województwie wielkopolskim dziewięć gmin, a województwie śląskim dziesięć ankietowanych gmin (tabela 4.). 
TABELA 4.

Prowadzenie badań satysfakcji odbiorców usług komunalnych przez samorządy terytorialne w roku 2015 (w \% ważnych odpowiedzi)

\begin{tabular}{|l|c|c|}
\hline \multirow{2}{*}{$\begin{array}{c}\text { Województwo } \\
\text { podlaskie }\end{array}$} & \multicolumn{2}{|c|}{$\begin{array}{c}\text { Czy na terenie gminy są przeprowa- } \\
\text { dzane badania satysfakcji odbiorców } \\
\text { usług komunalnych? }\end{array}$} \\
\cline { 2 - 3 } & tak & nie \\
\hline śląkie & 2,3 & 97,7 \\
wielkopolskie & 9,3 & 90,7 \\
ogółem & 8,3 & 91,7 \\
& 7,7 & 92,3 \\
\hline
\end{tabular}

Źródło: opracowanie własne na podstawie wyników badań ankietowych.

Gminy, które zadeklarowały prowadzenie takiego monitoringu, najczęściej realizowały go w następujących dziedzinach (uszeregowano je, zaczynając od najczęściej wymienianych dziedzin):

- gospodarka odpadami komunalnymi,

- $\quad$ stan czystości ulic i terenów zielonych,

- jakość wody i usług dostarczania wody,

- transport publiczny,

- jakość pracy urzędu gminy i zadowolenie klienta,

- oświetlenie ulic,

- oferta sportowa i kulturalna,

- pomoc społeczna,

- mieszkalnictwo.

Pytanie związane z poziomem monitoringu jakości oferowanych usług pojawiło się również w poprzedniej edycji badań przeprowadzonych dla województwa śląskiego w roku 2012 (zarówno w badaniach gmin, jak i konsumentów) i od tego momentu nie odnotowano żadnego postępu.

\section{Podsumowanie}

Aktualnie funkcjonujący w wielu gminach system upowszechniania informacji publicznej oraz edukacji ekologicznej wciąż budzi wiele zastrzeżeń dotyczących np.: ograniczenia działań edukacyjnych tylko do wymaganego ustawowo minimum, dostępności i kompletności udzielanych informacji, przejrzystości i aktualności zawartości stron internetowych czy też sposobów przekazywania informacji osobom niekorzystającym z Internetu. Badania ankietowe przeprowadzone wśród gmin świadczą o pewnym zniechęceniu ze strony władz lokalnych, które nie widzą sensu prowadzenia aktywnej polityki informacyjno-edukacyjnej związanej z ekologia. Samorządy terytorialne wskazuja, że realną barierą rozwoju są złe i ugruntowane nawyki mieszkańców, często ich brak wiedzy ekologicznej oraz niechęć do ponoszenia opłat związanych z poprawa jakości środowiska. 
Jednocześnie często nie prowadzą aktywnych działań edukacyjno-informacyjnych mających na celu kształtowanie postaw proekologicznych. Jest to zadanie trudne i nieprzynoszące szybkich efektów, ale równocześnie jest to jedyny sposób na trwała zmianę postaw. Niejednokrotnie w działaniach władz publicznych przeważa świadomość, że dobre decyzje i inwestycje obronią się same, zaangażowanie i wydatki finansowe nie są potrzebne na aktywnie prowadzoną działalność informacyjna. Jak już wspomniano powyżej, braki takie niejednokrotnie przyczyniają się do powstawania sytuacji konfliktowych.

Podsumowując powyższe rozważania, można sformułować generalne zalecenie dotyczące szerszego stosowania przez gminy instrumentów partycypacyjnych, takich jak: informowanie, konsultowanie proponowanych rozwiązań i inwestycji, a następnie włączanie mieszkańców w proces podejmowania finalnych decyzji obejmujących kwestie kluczowe dla społeczności lokalnych. Władze lokalne powinny także regularnie prowadzić badania opinii publicznej w zakresie jakości świadczenia usług publicznych i uwzględniać uwagi związane z funkcjonowaniem tych systemów, natomiast bez tego nie jest łatwe budowanie zaufania społecznego i realnego zaangażowania mieszkańców w realizację proponowanych rozwiązań systemowych.

\section{Literatura}

Borys T., 1998, Jak budować programy ekorozwoju: informacje ogólne, Fundacja Karkonoska, Warszawa, Jelenia Góra.

Długosz D., Wygnański J., 2005, Obywatele wspótdecyduja. Przewodnik po partycypacji spotecznej, Stowarzyszenie na rzecz Forum Inicjatyw Pozarządowych, Warszawa.

Komunikat Wójta Gminy Babiak z dnia 14 września 2015 roku, http://bip.wokiss.pl/ babiak/ bip/wybory-i-referenda/referendum-gminne-2015.html (data wejścia: 01.07.2016).

Krzemiński J., Biogazownie budzq sprzeciw, http://ekorynek.com/oze/631-biogazownie-budza-sprzeciw (data wejścia: 23.06.2016).

Kwiatkowski J., 2003, Partycypacja społeczna i rozwój społeczny, Fundacja Rozwoju Demokracji Lokalnej, Warszawa.

Raport Ambiens: Konflikty społeczne w energetyce wiatrowej, Warszawa, czerwiec 2014, http://www.ambiens.pl/pliki/raport-konflikty-spoleczne-w-energetyce-wiatrowej2014.pdf (data wejścia: 02.07. 2016).

Stan środowiska w województnie ślaskim w roku 2014, 2015, Wojewódzki Inspektorat Ochrony Środowiska w Katowicach, Biblioteka Monitoringu Środowiska, Katowice.

Ubóstwo w Polsce w latach 2013 i 2014, 2016, GUS, Warszawa.

Wawer M., Dlaczego inwestycje w budowe biogazowni rolnicaych napotykaja na opór spoteczny?, Euro SCG Sensors, http://www.cdr.gov.pl/pol/projekty/AZE/prezentacje/ ERSCG_Kielce.pdf (data wejścia: 24.06.2016).

Województwo ślaskie w licz̧bach 2016, 2016, GUS, Katowice 2016.

Wybrane dane z. zakresu sytuacji spoleçno-gospodarczej wojewódz̨twa ślaskiego w maju 2016, 2016, GUS, Katowice.

Wyzwania zrónnoważonego rožnoju w Polsce, 2010, J. Kronenberg, T. Bergier (red.), Fundacja Sendzimira, Kraków. 